\title{
Impact of Follow-Up by the Child and Adolescent Psychiatrist on Emergency Department Re-Visit due to Child-Adolescent Psychiatric Causes
}

\author{
Çocuk Psikiyatristi Takibinde Olmanın Çocuk-Ergen Psikiyatrik \\ Nedenlerle Acil Servis Tekrar Başvurusu Üzerine Olan Etkisi
}

\section{Ramazan GÜVEN¹ id , Seda Aybüke SARI² id , Mahmut BÜYÜKŞIMŞEK id \\ ${ }^{1}$ Department of Emergency Medicine, Bitlis State Hospital, Bitlis, Turkey \\ 2Department of Child and Adolescent Psychiatry, Bitlis State Hospital, Bitlis, Turkey \\ ${ }^{3}$ Department of Internal Medicine, Bitlis State Hospital, Bitlis, Turkey}

\section{ABSTRACT}

Objective: Psychiatric causes of emergency department (ED) visits in childhood have been increasing more rapidly than the other causes. The rate of re-visit to the ED due to the same complaint is an important reason for ED visits. In the present study, we investigated the impact of follow-up of child-adolescent patients presenting to the ED due to psychiatric causes by the child and adolescent psychiatrist on ED re-visits due to the same complaint.

Methods: This retrospective single-center study was conducted on child-adolescent patients admitted to the ED for psychiatric reasons in the last 2 years. A total of 77 patients were included in the study. The patients were divided into two groups according to whether they were followed up by the child and adolescent psychiatrist. The first group included patients who were followed up by the child and adolescent psychiatrist, whereas the second group included patients who were not seen or not followed up by the child and adolescent psychiatrist.

Results: Child-adolescent patients in the first group who visited the ED due to psychiatric causes and were followed up by the child and adolescent psychiatrist had a significantly lower rate of ED re-visit due to the same complaint than those in the second group of who were not seen or followed up by the child and adolescent psychiatrist ( $\mathrm{p}=0.023)$.

Conclusion: Follow-up by child and adolescent psychiatrist plays an important role in decreasing the ED re-visit rate of child-adolescent patients presenting to the ED due to psychiatric reasons.

Keywords: Child and adolescent psychiatrist, emergency department, re-visit

\section{öz}

Amaç: Çocukluk çağı acil başvuruları arasında psikiyatrik nedenler diğer nedenlere göre daha hızlı oranda artmaktadır. Acil servise aynı şikayetle tekrar başvuru oranı acil başvurularının önemli bir nedenidir. Biz de bu çalışmayla psikiyatrik nedenlerle acil servise başvuran çocuk-ergen hastaların çocuk psikiyatrisi takibine girilmesi durumunda aynı şikayetle tekrar acil başvurusu üzerine olan etkisini inceledik.

Yöntemler: Retrospektif olarak analiz edilen bu çalışma, tek merkezli olup son 2 yılda acil servise psikiyatrik nedenlerle başvuran çocuk-ergen hastaları içermektedir. Çalışmaya 77 hasta dahil edildi. Bu hastalar çocuk psikiyatristi takibine göre iki gruba ayrıldı. Çocuk psikiyatristinin takibine giren hastalar birinci grubu, çocuk psikiyatristinin görmediği veya takibine girmedikleri hastalar ikinci grubu oluşturdu.

Bulgular: Psikiyatrik nedenlerle acil servise başvuran çocuk-ergen hastalardan çocuk psikiyatristinin takibine girdiği çalışmanın birinci grubunu oluşturan hastalar, çalışmanın ikinci grubuna giren çocuk psikiyatristinin görmediği veya takibine almadığı hastalara göre anlamlı bir şekilde daha az oranda acil servise aynı şikayetle tekrar başvurdukları tespit edildi $(\mathrm{p}=0,023)$

Sonuç: Çocuk psikiyatristi takibinin, psikiyatrik nedenlerle acil servise başvuran çocuk-ergen hastaların acil servis tekrar başvuru oranının azaltılmasında önemli bir katkısı olmaktadır.

Anahtar Kelimeler: Acil Servis, çocuk ve ergen psikiyatristi, tekrar başvuru

\section{Introduction}

Psychiatric causes are among the most common reasons for child emergency department (ED) visits (1). Since treatment of this patient group takes a long time, follow-up of these patients by the child and adolescent psychiatrist is important to prevent the recurrence of psychiatric episodes (2). Otherwise, these patients present to the ED due to the same complaint (3). ED re-visit due to the same complaint is considered as one of the reasons for ED overcrowding (4). Therefore, in this retrospective study, we investigated the impact of follow-up of child and adolescent patients by the child and adolescent psychiatrist on ED re-visit due to the same complaint.

Cite this article as: Güven R, Sarı SA, Büyükşimşek M. Impact of Follow-Up by the Child and Adolescent Psychiatrist on Emergency Department Re-Visit due to Child-Adolescent Psychiatric Causes. Bezmialem Science 2018; 6(3): 172-5. 


\section{Methods}

The present study was conducted retrospectively and covered the last 2 years. On average, 47,000 child patients present to the ED of our hospital annually. The files of 2743 patients who presented to the child and adolescent psychiatrist in the last 2 years were analyzed, and those who visited the ED due to psychiatric reasons in the last 2 years were recorded. The

\begin{tabular}{l|l|}
$\begin{array}{l}\text { Table 1. Reasons for emergency admission of patients } \\
\text { included in the study }\end{array}$ & $\%(n=77)$ \\
\hline & $45.5(35)$ \\
\hline Whole body convulsion or numbness & $27.3(21)$ \\
\hline Suicide attempt & $57.1(12)$ \\
\hline Drug overdose & $38.0(8)$ \\
\hline Injury by a sharp object & $4.7(1)$ \\
\hline Hanging & $9.1(7)$ \\
\hline Palpitation & $5.2(4)$ \\
\hline Harming others & $3.9(3)$ \\
\hline Meaningless speech, audiovisual hallucinations & $3.9(3)$ \\
\hline Abdominal pain & $2.6(2)$ \\
\hline Headache & $2.6(2)$ \\
\hline Dizziness
\end{tabular}

Table 2. Rate of emergency readmission of the study groups

First group Second group $(n=39) \%(n) \quad(n=38) \%(n)$

\begin{tabular}{l|c|c|}
\hline $\begin{array}{l}\text { Patients re-visiting } \\
\text { the emergency department }\end{array}$ & $2.6(1)$ & $18.4(7)$ \\
\hline $\begin{array}{l}\text { Patients not re-visiting } \\
\text { the emergency department }\end{array}$ & $97.4(38)$ & $81.6(31)$ \\
\hline
\end{tabular}

Table 3. Diagnoses established by the child and adolescent psychiatrist

$\%(n=39)$

Conversion disorder
Major depressive disorder
Panic disorder
Behavioral disorder
Acute stress disorder
Somatization disorder
Dissociative disorder
Bipolar disorder
Psychotic disorder
Schizophrenia

Conversion disorder

$17.9(7)$

$15.3(6)$

$15.3(6)$

$12.8(5)$

$12.8(5)$

$10.2(4)$

5.1 (2)

$5.1(2)$

2.5 (1)

2.5 (1) files in the archive of the Child and Adolescent Psychiatry Polyclinic were analyzed to determine if those patients were followed up by the child and adolescent psychiatrist. Children who had comorbid mental retardation and an organic disease including primarily epilepsy were not included in the study.

Annually, an average of 47,000 children present to the ED of our hospital. The files of patients who were admitted to the ED between June 2014 and September 2016 for psychiatric causes were reviewed. In that period, 89 children and adolescents presented to the ED for psychiatric causes. Those children who had a chronic comorbidity, such as mental retardation and epilepsy and any organic disease, were not included in the study. Furthermore, patients whose files were missing were excluded from the study. After patients who did not meet the inclusion criteria and whose files were missing were excluded, the remaining 77 patients were included in the study. The archives of the child and adolescent psychiatrist and hospital automation system were checked to determine if these patients were followed up by a child psychiatrist.

Patients were divided into two groups. The first group consisted of child-adolescent patients who visited the ED for psychiatric reasons and then followed up by the child and adolescent psychiatrist. The second group included child-adolescent patients who visited the ED for psychiatric reasons but did not visit the Child and Adolescent Psychiatry Polyclinic and thus were not followed up by the child and adolescent psychiatrist.

The child and adolescent psychiatrist in Bitlis State Hospital is the only one in the province and also accommodates patients from neighboring districts. Authors declared that the research was conducted according to the principles of the World Medical Association Declaration of Helsinki "Ethical Principles for Medical Research Involving Human Subjects".

\section{Statistical analysis}

Statistical analysis of patient data was performed using the IBM Statistical Package for the Social Sciences 22.0 (IBM SPSS Corp., Armonk, NY, USA). Categorical data are expressed as percentage. Chi-square test was used for comparison of differences between the groups in terms of frequencies. A p value $<0.05$ was considered as statistically significant.

\section{Results}

Of the 77 patients included in the study, $71.4 \%(\mathrm{n}=55)$ were girls, and $28.6 \%(n=22)$ were boys. The mean age of the patients was $14.8 \pm 2.1$ years; the youngest was 7 years, and the oldest was 17 years. The most common reasons for ED visits included syncope and/or whole body convulsion-numbness with $45.5 \%$ $(\mathrm{n}=35)$ and suicide attempt with $27.3 \%(\mathrm{n}=21)$. The most common method for suicide attempt was in the form of drug overdose with $57.1 \%(\mathrm{n}=12)$. Table 1 shows the other reasons for ED visits. Of the 77 patients included in the study, 39 were in the first group of patients who were followed up by the child and adolescent psychiatrist, and 38 were in the second group of patients who were not followed up by the child and adolescent psychiatrist. Of the patients, $2.6 \%(n=1)$ were in the first group, 
and $18.45 \%(\mathrm{n}=7)$ were in the second group who re-visited the $\mathrm{ED}$ due to psychiatric reasons $(\mathrm{p}=0.023)$ (Table 2).

As for the ED re-visits ratio due to psychiatric symptoms, the most common reason was suicide attempt with $19.0 \%$ (4 out of 21 patients). This was followed by palpitation with $14.2 \%$ ( 1 out of 7 patients) and syncope, whole body convulsion, or numbness with $8.5 \%$ ( 3 out of 35 patients).

An evaluation of the patients according to the reasons for ED visits revealed that all of the patients who presented due to psychotic symptoms, such as meaningless speech, audiovisual hallucinations, and somatic symptoms, such as abdominal pain, headache, and dizziness, were followed up by the child and adolescent psychiatrist. Of the patients, $71.4 \%(n=5)$ with complaint of palpitation, $42.8 \%(\mathrm{n}=15)$ with complaint of syncope and/or whole body convulsion-numbness, and $23.8 \%(\mathrm{n}=5)$ admitted due to suicide attempt were followed up by the child and adolescent psychiatrist.

The most common diagnostic categories of 39 patients who first visited the ED and then were followed up by the child and adolescent psychiatrist included conversion disorder with $17.9 \%$ $(\mathrm{n}=7)$, major depressive disorder with $15.3 \%(\mathrm{n}=6)$, panic disorder with $15.3 \%(\mathrm{n}=6)$, behavioral disorder with $12.8 \%(\mathrm{n}=5)$, generalized anxiety disorder with $12.8 \%(\mathrm{n}=5)$, and somatization disorder with $10.2 \%(n=4)$, respectively. Table 3 shows the other diagnostic categories of the patients. Major depressive disorder was the most common diagnosis established by the child and adolescent psychiatrist for children who attempted suicide. Furthermore, the most common reason for suicide attempt by these children and followed up by the child and adolescent psychiatrist was family-related problems with $22.1 \%(\mathrm{n}=17)$, followed by friend relationships with $2.6 \%(\mathrm{n}=2)$, school-related problems with $1.3 \%(\mathrm{n}=2)$, and sexual abuse with $1.3 \%(\mathrm{n}=2)$, respectively.

\section{Discussion}

Psychiatric causes account for 10\%-15\% of child-adolescent emergencies (5). Behavioral disorders, suicidal ideation or attempt, acute stress disorder, and causing harm to others are the most common reasons for visits of child and adolescent psychiatric patients to the $\mathrm{ED}(6)$.

There are several studies in the literature regarding child and adolescent patients who present to the EDs due to psychiatric complaints $(7,8)$. In our study, the most common reason for ED visit was found to be syncope and/or whole body convulsion-numbness. Suicide attempt was among the most common reasons for child-adolescent psychiatric patients to present to the EDs, which was consistent with the literature, whereas drug overdose was the most common method for suicide attempt (6). On the other hand, similar to another study, the most common diagnoses of patients followed up by the child and adolescent psychiatrist were found to be conversion disorder and major depressive disorder $(8,9)$. Contrary to a retrospective study conducted by Tanzer et al. (10) on pediatric forensic cases in which they concluded that road traffic accident is a preventable factor, we only assessed children and adolescent patients who presented to the ED for psychiatric causes in our study.

Today, an increased ED visit is an important problem worldwide (11). Overcrowding of EDs leads to some important problems, such as delays in the treatment of patients and increased hospital mortality (12). Therefore, some studies focused on specific methods to decrease ED overcrowding by eliminating the factors causing overcrowding $(13,14)$. The rate of ED re-visit due to the same complaint is $1 \%-11 \%$ and one of the important reasons for ED overcrowding (15-17).

The rate of re-visit with the same complaint of patients who presented due to suicidal reasons and were intervened by a psychiatrist was lower than that of patients who were not followed up by a psychiatrist (18). Erlangsen et al. (19) obtained similar results in their short-term and long-term follow-up cohort study. In the present study on child-adolescent psychiatric patients, we found that the rate of ED re-visit with the same complaint of the first group of patients who were followed up by the child and adolescent psychiatrist was significantly lower than that of the second group of patients who were not followed up by the child and adolescent psychiatrist.

Of the patients, $20 \%-25 \%$ who presented to the ED due to suicide attempt have a second suicide attempt, and 5\%-10\% of them result in death according to previous studies (20). Mutlu et al. (21) conducted a study in which they emphasized the importance of a patient who was admitted to the ED due to suicide attempt. In their study on adolescents with behavioral disorders, they concluded that suicide attempt is an important factor to predict hospitalization. In our study, we found that child-adolescent patients who attempted suicide re-visited the ED due to the second suicide attempt at a similar rate. Patients who attempted suicide were followed up by the child and adolescent psychiatrist at a lower rate, whereas they had a higher rate of $\mathrm{ED}$ visits than the other reasons of $\mathrm{ED}$ visits.

\section{Study limitations}

The present study has some limitations. Poor socioeconomic and educational level of the local people, negative and prejudiced views about psychiatric treatment, reluctance of families for patient management, and cooperation and secondary results of $\mathrm{ED}$ visits are negative factors that increase the number of patients who are not followed up and the rate of ED re-visits. Our study was a retrospective study and included a low number of patients.

\section{Conclusion}

Child-adolescent psychiatric patients constitute one of the most challenging patient groups that are difficult to manage at the ED (22). In addition, it was demonstrated by our study that the rate of re-visit of these patients due to the same complaint increased unless they were followed up by the child and adolescent psychiatrist. Therefore, specific measures should be taken, and efforts should be undertaken in order to ensure that child-adolescent psychiatric patients are followed up by the child-adolescent psychiatrists. 
Ethics Committee Approval: Authors declared that the research was conducted according to the principles of the World Medical Association Declaration of Helsinki "Ethical Principles for Medical Research Involving Human Subjects”, (amended in October 2013).

Informed Consent: Due to the retrospective design of the study, informed consent was not taken.

Peer-review: Externally peer-reviewed.

Author Contributions: Concept - R.G., S.A.S.; Design - R.G., S.A.S.; Supervision - M.B., R.G., S.A.S.; Data Collection and/or Processing - M.B., R.G., S.A.S.; Analysis and/or Interpretation M.B., R.G., S.A.S.; Literature Search - M.B., R.G., S.A.S.; Writing Manuscript - R.G., S.A.S.; Critical Review - M.B., R.G., S.A.S.

Conflict of Interest: Authors have no conflicts of interest to declare.

Financial Disclosure: The authors declared that this study has received no financial support.

Etik Komite Onayı: Yazarlar çalışmanın World Medical Association Declaration of Helsinki "Ethical Principles for Medical Research Involving Human Subjects”, (amended in October 2013) prensiplerine uygun olarak yapıldığını beyan etmişlerdir.

Hasta Onamı: Çalışmanın retrospektif tasarımından dolayı hasta onamı alınamamıştır.

Hakem Değerlendirmesi: Dış bağımsız.

Yazar Katkıları: Fikir - R.G., S.A.S.; Tasarım - R.G., S.A.S.; Denetleme - M.B., R.G., S.A.S.; Veri Toplanması ve/veya İşlemesi - M.B., R.G., S.A.S.; Analiz ve/veya Yorum - M.B., R.G., S.A.S.; Literatür Taraması - M.B., R.G., S.A.S.; Yazıyı Yazan - R.G., S.A.S.; Eleştirel İnceleme - M.B., R.G., S.A.S.

Çıkar Çatışması: Yazarlar çıkar çatışması bildirmemişlerdir.

Finansal Destek: Yazarlar bu çalışma için finansal destek almadıklarını beyan etmişlerdir.

\section{References}

1. Christodulu KV, Lichenstein R, Weist MD, Shafer ME. Psychiatric emergencies in children. Ped Emerg Care 2002; 18: 26870. [CrossRef]

2. Callahan J. Crisis theory and crisis intervention in emergencies. In: Kleepsies PM, ed. Emergencies in Mental Health Practice. New York: Guilford Press; 1998:22-40.

3. Kanehara A, Yamana H, Yasunaga H, Matsui H, Ando S, Okamura, et al. Psychiatric intervention and repeated admission to emergency centres due to drug overdose. BJ Psych Open 2015; 1: $158-63$.

4. Akyol C, Oktay C, Hakbilir O, Akyol AJ, Tür FÇ. Acil Servise Aynı Şikayet ile Tekrar Başvuran Hastaların Değerlendirilmesi. Turk J Emerg Med 2006; 6: 108-16.

5. Fleitlich-Bilyk B, Goodman R. Prevalence of child and adolescent psychiatric disorders in southeast Brazil. J Am Acad Child Adolesc Psychiatry 2004; 43: 727-34. [CrossRef]

6. American Academy of Childs, American College of Emergency Physicians, Dolan MA, Mace SE. Child mental health emer- gencies in the emergency medical services system. American College of Emergency Physicians. Ann Emerg Med 2006; 48: 484-6.

7. Scivoletto S, Boarati MA and Turkiewicz G. Psychiatric emergencies in childhood and adolsecence. Revista Brasileira Psiquiatria 2010; 32: 112-20. [CrossRef]

8. Tokgöz Y, Güvenir T, Duman M, Yılmaz D. Psychiatric Emergencies In Adolescent. Journal of Pediatrics Speciality Academy 2014; 2: 1-3.

9. Ünlü G, Aksoy Z, Ersan EE. Evaluation of child and adolescents with attempted suicide. Pam Med J 2014; 7: 176-83. [CrossRef]

10. Tanzer K, Erkol Z, Kahramansoy N. Evaluation of Pediatric Forensic Cases in Emergency Department: A Retrospective Study. The Medical Bulletin of Haseki Training and Research Hospital 2014; 52: 271-7. [CrossRef]

11. Gillam S. Rising hospital admissions. BMJ 2010; 340: 275-6. [CrossRef]

12. Bernstein SL, Aronsky D, Duseja R, Epstein S, Handel D, Hwang U, et al. The effect of emergency department crowding on clinically oriented outcomes. Acad Emerg Med 2009; 16: 1-10. [CrossRef]

13. Hoot NR, Dominik Aronsky D. Systematic Review of Emergency Department Crowding: Causes, Effects, and Solutions. Ann Emerg Med 2008; 52: 126-36. [CrossRef]

14. Derlet RW, Richards JR. Ten Solutions for Emergency Department Crowding. West JEM 2008; 9: 24-7.

15. Cardin S, Afilalo M, Lang E, Collet JP, Colacone A, Tselios C, et al. Intervention to decrease emergency department crowding: does it have an effect on return visits and hospital readmissions? Ann Emerg Med 2003; 41: 173-85. [CrossRef]

16. Gordon JA, An LC, Hayward RA, Williams BC. Initial emergency department diagnosis and return visits: risk versus perception. Ann Emerg Med 1998; 32: 56. [CrossRef]

17. Liaw SJ, Bullard MJ, Hu PM, Chen JC, Liao HC. Rates and causes of emergency department revisits within 72 hours. J Formos Med Assoc 1999; 98: 422-5.

18. Kawanishi C, Aruga T, Ishizuka N, Yonemoto N, Otsuka K, Kamijo Y, et al. Assertive case management versus enhanced usual care for people with mental health problems who had attempted suicide and were admitted to hospital emergency departments in Japan (ACTION-J): a multicentre, randomised controlled trial. Lancet Psychiatr 2014; 3: 193-201. [CrossRef]

19. Erlangsen A, Lind B, Stuart E, Qin P, Stenager E, Larsen K, et al. Short-term and long-term effects of psychosocial therapy for people after deliberate self-harm: a register-based, nationwide multicentre study using propensity score matching. Lancet Psychiatr 2015; 2: 49-58. [CrossRef]

20. Larkin GL, Beautrais AL. Emergency departments are underutilized sites for suicide prevention. Crisis 2010; 31: 1-6. [CrossRef]

21. Mutlu C, Özdemir M, Yorbik O, Kilicoglu AG. Possible Predictors of Hospitalization for Adolescents with Conduct Disorder Seen in Psychiatric Emergency Service. Dusunen Adam 2015; 28: 301-8. [CrossRef]

22. Case SD, Case BG, Olfson M, Linakis JG, Laska EM. Length of Stay of Child Mental Health Emergency Department Visits in the United States. Am Acad Child Adolesc Psychiatry 2011; 50: 1110-9. [CrossRef] 